\title{
Mineral Content and Mycotoxin Level in Different Classes of Cheese Marketed in Sharkia Governorate, Egypt
}

\author{
Eman Nabil Abdelfatah \\ Food Control Department, Faculty of Veterinary Medicine, Zagazig Univeristy, Zagazig, Egypt
}

Email address:

Dr.emannabil@hotmail.com

To cite this article:

Eman Nabil Abdelfatah. Mineral Content and Mycotoxin Level in Different Classes of Cheese Marketed in Sharkia Governorate, Egypt. International Journal of Nutrition and Food Sciences. Vol. 4, No. 2, 2015, pp. 154-160. doi: 10.11648/j.ijnfs.20150402.15

\begin{abstract}
Ninety (90) different local (small scale and large scale) and imported cheese samples which were consumed by different classes of consumers were collected from different markets in Sharkia, Egypt for analyzing them for mineral content and mycotoxin level. The results revealed that 9 out of 30 examined small scale cheese samples $(30 \%)$ were contaminated by ochratoxin A(OTA), the minimum was $2.0 \mathrm{ppb}$ and the maximum was $5.0 \mathrm{ppb}$, while only $7 / 30$ (23.33\%) of examined large scale cheese samples were contaminated by OTA with a mean value of $1.98 \pm 0.32 \mathrm{ppb}$. On the other side imported cheese samples was contaminated by OTA by percentage of $36.67 \%$. All the positive samples of the three types were Exceeding Egyptian regulation permissible limits (P.L.). Regarding aflatoxin M1 (AFM1) level in the examined samples the results showed that the small scale samples have the highest contamination level with AFM1 recording 56.67\% (17 out of 30) with levels ranging from 32.3 to 50.2 $\mathrm{ng} / \mathrm{kg}$ and all the positive samples had AFM1 levels exceeding Egyptian regulation P.L., while the lowest AFM1 contamination level present in the imported cheese samples recording $33.33 \%$ with a mean $25.74 \pm 1.82 \mathrm{ng} / \mathrm{kg}$. Trace and heavy metals including $\mathrm{Pb}, \mathrm{Cd}, \mathrm{Hg}, \mathrm{Cu}$ and $\mathrm{Zn}$ were present in the range of $\mathrm{Zn}>\mathrm{Pb}>\mathrm{Cu}>\mathrm{Cd}>\mathrm{Hg}$ in small scale and imported cheese samples, while in large scale samples it was in the order of $\mathrm{Pb}>\mathrm{Cu}>\mathrm{Cd}>\mathrm{Zn}>\mathrm{Hg}$. The results of this study indicate that continuous monitoring of chemical contaminant levels in different types of cheese consumed by different classes of consumers in Sharkia Governorate should be regularly done. It also shows an alarming situation with respect to cheeses produced from all classes (small scale, large scale and even imported types).
\end{abstract}

Keywords: AFM1, OTA, Heavy Metals, Cheese, P.L.

\section{Introduction}

Milk is considered as a nearly complete food, since it is a good source of protein, fat and major minerals. Also, milk and milk products are the main constituents of the daily diet, especially for vulnerable groups such as infants, school age children and old age [1]. Cheese present among these products and it is known to be of great nutritional value for human consumption as its fat and protein have a high biological value and contains all essential fatty and amino acids. Also, it is a source of vitamins and minerals [2]. Cheese was previously classified under "safe foods" but after 1980, many reports of infections and intoxications related to the consumption of contaminated cheese which poses a threat to public health and also quality defects in cheese leads to big economic losses [3].

Mycotoxins are among the environment chemical agents that exert toxic effects on animals and humans [4]. Aflatoxins are a group of mycotoxins mainly produced by some species of aspergillus namely Aspergillus flavus, Aspergillus parasiticus and Aspergillus nomius [5]. These fungi grow under particular conditions of temperature and humidity and can occur in a wide range of agricultural commodities such as cereals, nuts, spices and feed materials [6].

Aflatoxin M1 (AFM1) is a hydroxylated metabolite of aflatoxin B1 and can be detected in milk and dairy products from dairy cattle that have ingested feed contaminated with aflatoxin B1 [7]. The level of AFM1 in raw milk is a concern due to its mutagenic, carcinogenic and teratogenic effects [8] and considered as major etiological factors for hepatocellular carcinoma (HCC) [9]. It is assumed that neither storage nor processing could destroy the AFM1 toxin [10] and can be detected in dairy products submitted to pasteurization and sterilization process and also in fermented products [11].

The occurrence of AFM1 in cheese may be due to AFM1 contamination of raw milk used in cheese manufacture, synthesis of aflatoxins by Aspergillus flavus and Aspergillus parasiticus growing on cheese [12] or by the occurrence of 
AFM1 in powdered milk used in cheese manufacture [13]. Consequently AFM1 can also be present in all dairy products manufactured with contaminated milk at an amount superior to that in milk [14].

The most important toxic metabolite produced by several Penicillium moulds is ochratoxin A (OTA), a chlorinated polyketide mycotoxin containing the amino acid Lphenylalanine, which shows nephrotoxic, teratogenic, immunogenic, hepatotoxic and carcinogenic activities and has been classified as a Group 2B carcinogen by the International Agency for Research on Cancer [15]. OTA is produced also by different species of aspergillus (Aspergillus ochraceus, Aspergillus melleus, Aspergillus sulphureus, Aspergillus nigri, Aspergillus lanosus, Aspergillus alliaceus, Aspergillus carbonarius and Aspergillus awamori) and penicillium (Penicillium verrucosum, Penicillium chrysogenum and Penicillium nordicum) [16-17]. OTA might be produced on the surface of cheese by penicillia during the ripening [18].

Cheese is exposed to different types of contamination during manufacture with different kinds of heavy metals such as cadmium, nickel, lead, copper and mercury [19]. Trace metals may enter our foods from a number of sources like soil, chemicals used to agricultural land, water used in food processing or cooking, equipment, containers and utensils used for food processing, packaging, storage and cooking [20]. It causes many health problems such as weakness, heart failure, induced cancer diseases [21] and also affects the kidney. In case of food safety assessment it should be taken into account that the heavy metals like $\mathrm{Cr}, \mathrm{Co}, \mathrm{Cu}, \mathrm{Fe}, \mathrm{Mn}$ and $\mathrm{Zn}$ are essential, which are so called micronutrients.

Deficiency of any one of essential metal nutrients will result in specific biochemical lesions within cells of the body and subsequently development of certain characteristic clinical symptoms which will normally alleviate when the deficiency is corrected by supplying an adequate amount of the missing element. Although these metals are essential for health, excessive exposure may be hazardous [22], whereas the heavy metals especially $\mathrm{Pb}, \mathrm{Cd}, \mathrm{Hg}$ and $\mathrm{As}$ are non essential elements and even toxic in trace levels [23 - 24].

Therefore, this study was conducted to make a survey on presence of some mycotoxins (AFM1 and OTA) and heavy metals $(\mathrm{Pb}, \mathrm{Cd}, \mathrm{Hg}, \mathrm{Cu}$ and $\mathrm{Zn})$ in small scale, large scale and imported cheese to assess their quality and determine the amount of these toxic substances that consumed by different classes of Egyptian consumers.

\section{Materials and Methods}

\subsection{Collection of Samples}

A total number of 90 commercial cheese samples of different kinds and origin were collected from different supermarkets in Sharkia Governorate, Egypt (30 for each of small scale, large scale and imported cheese samples). Small scale sample were represented by 250 grams which was apparently of good condition while large scale and imported samples were collected in its original package. The samples were transported to the laboratory inside an insulated container at about $4{ }^{\circ} \mathrm{C}$ and analyzed directly after arrival.

\subsection{Determination of OTA Content}

The detection of OTA residues in collected cheese take place using immunoaffinity column method for extraction of ochratoxin A and reading by VICAM fluorometer in parallel with standard of OTA [25]. Preparation of samples took place acc.to [2].

Column Chromatography: Pass $10 \mathrm{ml}$ diluted extract completely through the ochraTest affinity column at a rate of about 1-2 drops/ second until air comes through the column. Pass $10 \mathrm{ml}$ of mycotoxin wash buffer through the column at a rate of 1-2 drops/ second. Pass $10 \mathrm{ml}$ of purified water through the column at a rate of 1-2 drops/ second until air comes through the column. Elute affinity column by passing $1.5 \mathrm{ml}$ OchraTest eluting solution through the column at a rate of 1 drops/ second and collecting all of the sample elute in a glass cuvette. Mix well and place cuvette in a calibrated fluorometer, read ochratoxin concentration after 60 seconds.

\subsection{Determination of AFM1 Content}

Cheese samples were prepared according to the method outlined in the ELISA kit [26] then use the enzyme-linked immunosorbent assay (ELISA). Using Ridascreen AFM1 kits (R-Biopharm, Derm-Stadt, Germany), which contained Microtiter plates coated with specific antibodies to AFM1, AFM1 standard solution of $(0,5,10,20,40$, and $80 \mathrm{ng} \backslash \mathrm{L})$, peroxidase conjugated AFM1, together with substrate chromogen and stop solution. All samples were prepared and defattened using the method outlined in the ELISA kits, as briefly described in [26]

\subsection{Chemical Analysis of Mineral Content}

One gram of cheese samples was digested with $5 \mathrm{ml}$ concentrated nitric acid over night. The mixture was heated at $70^{\circ} \mathrm{C}$ for 2 hours and filtered through Whitman filter paper No. 42. The filtrate was completed to $50 \mathrm{ml}$ with deionized water. All samples were analyzed using Air-acetylene unit in (Perkin Elmer model, spectra-AA10, USA) Atomic Absorption Spectrophotometer" for determination of Lead, Cadmium, Mercury, Cupper and Zinc according to [27- 28].

\subsection{Data Analysis}

The collected data is presented as mean and standard error and subjected to one-way Analysis of Variance (ANOVA). All statistical calculations were performed with SPSS 9.0 for Windows.

\section{Results and Discussion}

\subsection{Ochratoxin}

The results given in table 1 revealed that 9 out of 30 examined small scale cheese samples (30\%) were contaminated by OTA, the minimum was $2.0 \mathrm{ppb}$ and the 
maximum was $5.0 \mathrm{ppb}$, while only $7 / 30(23.33 \%)$ of examined large scale cheese samples were contaminated by OTA with a mean value of $1.98 \pm 0.32 \mathrm{ppb}$. On the other side imported cheese samples were contaminated by OTA by percentage of $36.67 \%$. All the positive samples of the three types were exceeding Egyptian regulation permissible limits.

Previous studies on the subject provided that OTA was present in 6 samples out of Thirty-two traditional hand-made semi-hard cheeses with concentration ranged from 1 to 262 $\mu \mathrm{g} / \mathrm{kg}$ in the rind and from 18 to $146 \mu \mathrm{g} / \mathrm{kg}$ in the cheese interior [29]. On the other side Awad et al. [2] reported that 12 out of examined 20 small scale manufactured roomy cheese samples, $(60 \%)$ were contaminated by OTA, the minimum detected level was $2.0 \mathrm{ppb}$, the maximum was 7.0 ppb and the mean value was $3.67 \pm 0.22 \mathrm{ppb}$ while only 6 (30\%) out of examined large scale manufactured roomy cheese samples were contaminated by OTA. The level of contamination detected ranged from $2.0 \mathrm{ppb}$ to $5.0 \mathrm{ppb}$ with a mean value of $3.92 \pm 0.30 \mathrm{ppb}$.

Mould strains able to produce OTA can be part of the environmental microflora of various food items and cheese-making factories [30-31]. Thus, cheese making, ripening and storage should be strictly monitored to prevent contamination. It is well known that moulds developing on cheese rinds generally come from the environment; thus, the wooden shelves on which traditional cheeses are placed during ripening could also be a source of mycotoxin-producing moulds [32-31]. Chances of mycotoxins production are very small when dairy products are kept at refrigeration temperature and good hygiene practice is very important to fight mould spoilage. Because air is generally an effective vehicle for distribution of mould, filtration of air and even the practice of clean room technique had been introduced in some places. Vacuum packaging or modified atmosphere packaging was used to inhibit mould growth and application of chemical inhibitors on wrapping and product surface was also used [33].

OTA is a nephrotoxic, teratogenic and carcinogenic compound and may also cause immunotoxic effects [34-35]. Due to its nephrotoxicity, OTA has been regarded as an important factor for human endemic nephropathy in the Balkan area [36].

\subsection{Aflatoxin M1}

90 different cheese samples from different countries were collected from Sharkia markets for the analysis of AFM1 (Table 2). The results showed that the small scale samples had the highest contamination level with aflatoxin M1 recording $56.67 \%$ (17 out of 30 ) with levels ranging from 32.3 to $50.2 \mathrm{ng} / \mathrm{kg}$ and all the positive samples had AFM1 levels exceeding Egyptian regulation permissible limit, while the lowest AFM1 contamination level present in the imported cheese samples recording $33.33 \%$ with a mean $25.74 \pm 1.82 \mathrm{ng} / \mathrm{kg}$.

In comparison with other studies conducted in the nearby region, in Iran $82.5 \%$ of 80 feta cheese samples tested positive for AFM1 and in $60.6 \%$ of the positive samples,
AFM1 levels exceeded the maximum acceptable levels [37] while AFM1 levels in $18 \%$ of 100 cream cheese samples in Turkey exceeded the action limit of $250 \mathrm{ng} / \mathrm{kg}$ [38]. In another study in Kuwait, The cheese samples recorded $80 \%$ contamination with AFM1 with a range $23.8-452 \mathrm{ng} / \mathrm{kg}$ and mean of $87.6 \mathrm{ng} / \mathrm{kg}$, with one sample being above the regulatory limit $(250 \mathrm{ng} / \mathrm{kg})$ [7].

Tavakoli et al. [39] reported that AFM1 was found in $60 \%$ of the cheese samples ranging from 40.9 to $374 \mathrm{ng} / \mathrm{kg}$. Toxin levels in $6 \%$ of the samples exceeded the Iranian national standard limit, i.e. $200 \mathrm{ng} / \mathrm{kg}$. While Elkak et al. [40] recorded that AFM1 was detected in $67.56 \%$ out of the 111 samples analyzed in which the levels of AFM1 in $17.33 \%$ of the samples were found to exceed the limits $(250 \mathrm{ng} / \mathrm{kg})$ allowed by the European Commission (EC).

On the other hand Mohajeri et al. [41] found that AFM1 was detected in $29(64.4 \%)$ white cheese within range: 93.3-309 ng/kg. 9 samples (20\%) of white cheese had levels above the limit According to Iranian national standard limit for AFM1 in cheese $(200 \mathrm{ng} / \mathrm{kg})$.

These significantly variable AFM1 levels may be due to several influencing factors such as cheese manufacturing procedures and storage [42], types of cheese, conditions of cheese ripening [43], analytical methods and finally the geographical and seasonal effects [10]. In addition, the storage conditions of products including humidity and temperature are also important for toxin production. Cheese is the most potent source of aflatoxin among foods because of the AFM1 associated with the casein fraction in milk [44]. In addition, studies done on AFM1 concentration changes in cheese showed no significant change of concentration even after 3 months of storage [42]. It is important to mention that the stability of AFM1 during processing and storage makes it dangerous.

Generally, presence of aflatoxins in animal or human bodies cause a disease named Aflatoxicosis, so the presence of AFM1 may be specified as Aflatoxicosis M1[45]. Aflatoxicosis causes anemia, reduction of immune function, hepatotoxicosis, hemorrhage, teratogenesis, carcinogenesis and mutagenesis. The most prevalent symptoms of aflatoxicosis in animals are reduced growth rate and poor intellectual and behavioral performance. The liver is considered a target organ for the toxic and carcinogenic effects of AFM1 [46-47]. Several studies indicate that exposure to AFM1 has a possible link to an increased risk of developing cancer in humans [48]. The carcinogenicity of AFM1 may be influenced by the duration and level of exposure [49].

\subsection{Heavy Metals}

Tables 3 and 5 summarized the results of analyzed heavy metals obtained in this study and Previous related results from various parts of the world. Results obtained in this investigation concerning Chemical analysis revealed the presence of $\mathrm{Pb}, \mathrm{Cd}, \mathrm{Hg}, \mathrm{Cu}$ and $\mathrm{Zn}$. The concentration of some minerals and heavy metals was in the order of $\mathrm{Zn}>\mathrm{Pb}>$ $\mathrm{Cu}>\mathrm{Cd}>\mathrm{Hg}$ in small scale and imported cheese samples, 
while in large scale samples it was in the order of $\mathrm{Pb}>\mathrm{Cu}>$ $\mathrm{Cd}>\mathrm{Zn}>\mathrm{Hg}$.

The statistical analysis of obtained data (Table 4 ) revealed that none of examined cheese samples having $\mathrm{Hg}$ or $\mathrm{Zn}$ levels above the recommended permissible limit. While, 9 (30\%), 7 (23.33\%) and 7 (23.33\%) out of 30 examined small scale, large scale and imported cheese samples respectively having $\mathrm{Cu}$ levels above the permissible limit. However, 2 $(6.67 \%)$ out of 30 in the examined three types of cheese having cd levels above the permissible limit and finally 6 $(20 \%), 4(13.33 \%)$ and $3(10 \%)$ out of 30 examined small scale, large scale and imported cheese samples respectively having pb levels above the permissible limit recommended by Egyptian standard (1993).

The trace metal content of cheese is variable because of factors such as differences between species, geographical area, characteristics of the manufacturing procedures and possible contamination from the equipment during the process, packaging, and storage. It is necessary to control the manufacturing process at each step in order to determine the source and levels of contamination and to ensure the desired product quality [19]. This could be result of contamination during the cheese making process. Coni et al. [50] indicated that the release of heavy metals from the equipment to the cheese might occur during processing at a relatively high temperature.

It seems that the use of stainless steel containers, appropriate packaging and agricultural products grown in soils with low heavy metal pollution could play major role in reduction of heavy metal content in dairy product [51]. The selection of a suitable packaging material has an important in cheese packaging. Because a toxicological effect of component migration from packages into foods is crucial problem. Food packaging can interact with the packaged foodstuff by diffusion-controlled processes, which mainly depend on chemical properties of the food contact material and the foodstuff, temperatures at packaging, during heat treatment and storage, exposure to UV light and storage time of the product. This interaction can lead to control of food material compounds leaching from the packaging to the food [52].

Regarding the public health hazards of the detected metals, $\mathrm{Pb}$ is a potent neurotoxin for which no safety threshold has yet been found [53]. It may cause damage to kidneys, the cardiovascular, immune, hematopoietic, central nervous and reproductive systems. Short term exposure to high level of lead can cause gastrointestinal distress, anemia, encephalopathy and death [54].

Manifestations of lead poisoning are nonspecific abdominal pain, constipation, irritability, myalgia, muscle aches, headache, anorexia and decreased lipid concentrations. $\mathrm{Cd}$ has estrogenic properties and causes an increased incidence of cancer in mice [55]. Cadmium and its adverse health effects occur in the form of kidney damage but possibly also bone effects and fractures [56]. Chronic exposure to $\mathrm{Cd}$ and $\mathrm{Pb}$ is associated with kidney damage in adults [57]. Mercury is a particular cumulative poison and acts as an inhibitor for numerous enzymes. Moreover, it causes severe kidney damage in both man and animals [58].

On the other hand $\mathrm{Cu}$ is an essential element for several enzymes. The gastrointestinal absorption of $\mathrm{Cu}$ is normally regulated by body store and most of the $\mathrm{Cu}$ is stored in the liver and bone marrow where it is bound to metallothioneine [59]. Finally, $\mathrm{Zn}$ is an essential constituent or cofactor for more than 200 mettalloenzymes, hormones and hormone receptors, protein, neuropeptides and polynucleotides [60]. Excess amount of $\mathrm{Zn}$ causes diarrhoea, hair loss, brittle fingernails, weakness, anaemia and stomach \& intestine problems [61]. $\mathrm{Zn}$ does not accumulate with continued exposure but the body content is modulated by homeostatic mechanisms that act principally on the absorption and liver level [62].

Table 1. Occurrence of OTA (ppb/kg) in cheese samples in Sharkia Governorate and Comparing the detected levels to levels of the existing Egyptian regulation:

\begin{tabular}{lllllll}
\hline Product & $\begin{array}{l}\text { Examined } \\
\text { samples N. }\end{array}$ & $\begin{array}{l}\text { Positive samples } \\
\mathbf{N}(\mathbf{\%})\end{array}$ & $\begin{array}{l}\text { Min-max } \\
(\mathbf{p p b})\end{array}$ & $\begin{array}{l}\text { Mean } \pm \text { SE } \\
(\mathbf{p p b})\end{array}$ & \multicolumn{2}{c}{ Exceeding Egyptian regulation a (Ni) } \\
\cline { 6 - 8 } & 30 & $9(30 \%)$ & $2.0-5.0$ & $3.19 \pm 0.33$ & $\mathbf{N}$ & $100 \%$ \\
\hline Small scale cheese & 30 & $7(23.33 \%)$ & $1.0-3.0$ & $1.98 \pm 0.32$ & 7 & $100 \%$ \\
Large scale cheese & 30 & $11(36.67 \%)$ & $0.6-1.2$ & $0.83 \pm 0.65$ & 11 & $100 \%$ \\
Imported cheese & 30 & &
\end{tabular}

$\mathrm{a}-[63]$.

Table 2. Occurrence of AFM1 (ng/kg) in cheese samples in Sharkia Governorate and Comparing the detected levels to levels of the existing Egyptian regulation:

\begin{tabular}{|c|c|c|c|c|c|c|}
\hline \multirow{2}{*}{ Product } & \multirow{2}{*}{$\begin{array}{l}\text { Examined } \\
\text { samples } \mathrm{N} \text {. }\end{array}$} & \multirow{2}{*}{$\begin{array}{l}\text { Positive samples } \\
\text { N (\%) }\end{array}$} & \multirow{2}{*}{$\begin{array}{l}\text { Min-max } \\
(\mathrm{ng} / \mathrm{Kg})\end{array}$} & \multirow{2}{*}{$\begin{array}{l}\text { Mean } \pm \text { SE } \\
(\mathrm{ng} / \mathbf{K g})\end{array}$} & \multicolumn{2}{|c|}{ Exceeding Egyptian regulation ${ }^{\mathrm{b}}(0.0 \mu \mathrm{g} / \mathrm{kg})$} \\
\hline & & & & & $\mathbf{N}$ & (\%) \\
\hline Small scale cheese & 30 & $17(56.67 \%)$ & $32.3-50.2$ & $39.83 \pm 1.60$ & 17 & $100 \%$ \\
\hline Large scale cheese & 30 & $13(43.33 \%)$ & $23.2-47.1$ & $33.08 \pm 2.32$ & 13 & $100 \%$ \\
\hline Imported cheese & 30 & $10(33.33 \%)$ & 19.4-33.4 & $25.74 \pm 1.82$ & 10 & $100 \%$ \\
\hline
\end{tabular}

b- [64]. 
Table 3. The heavy metal residues in the examined cheese samples:

\begin{tabular}{|c|c|c|c|c|}
\hline & & Small scale cheese & Large scale cheese & Imported cheese \\
\hline \multirow{3}{*}{$\begin{array}{l}\text { Lead } \\
(\mathrm{ppm})\end{array}$} & Min & 0.17 & 0.09 & 0.15 \\
\hline & Max & 0.94 & 0.70 & 0.94 \\
\hline & Mean \pm S.E & $0.313 \pm 0.036$ & $0.223 \pm 0.026$ & $0.251 \pm 0.031$ \\
\hline \multirow{2}{*}{$\begin{array}{l}\text { Cadmium } \\
\text { (ppm) }\end{array}$} & Max & 0.39 & 0.60 & 0.15 \\
\hline & Mean \pm S.E & $0.045 \pm 0.013$ & $0.065 \pm 0.020$ & $0.033 \pm 0.005$ \\
\hline \multirow{2}{*}{$\begin{array}{l}\text { Mercury } \\
(\mathrm{ppb})\end{array}$} & Min & 0.015 & 0.009 & 0.003 \\
\hline & Mean \pm S.E & $0.022 \pm 0.0011$ & $0.013 \pm 0.0007$ & $0.010 \pm 0.0009$ \\
\hline \multirow{3}{*}{$\begin{array}{l}\text { Cupper } \\
(\mathrm{ppm})\end{array}$} & Min & 0.17 & 0.07 & 0.02 \\
\hline & Max & 0.86 & 0.65 & 0.49 \\
\hline & Mean \pm S.E & $0.327 \pm 0.037$ & $0.251 \pm 0.027$ & $0.221 \pm 0.023$ \\
\hline \multirow{3}{*}{$\begin{array}{l}\text { Zinc } \\
(\mathrm{ppm})\end{array}$} & Min & 0.029 & 0.13 & 3.4 \\
\hline & Max & 0.98 & 0.59 & 8.9 \\
\hline & Mean \pm S.E & $0.399 \pm .0498$ & $0.320 \pm 0.0281$ & $4.99 \pm 0.281$ \\
\hline
\end{tabular}

Table 4. The examined cheese samples that comply with the permissible limits for the analyzed heavy metals

\begin{tabular}{|c|c|c|c|c|c|c|c|}
\hline \multirow[t]{2}{*}{ Metals } & \multirow{2}{*}{$\begin{array}{l}\text { Permissible } \\
\text { limits } \\
(\mathrm{mg} / \mathrm{Kg})^{\mathrm{c}}\end{array}$} & \multicolumn{2}{|c|}{$\begin{array}{l}\text { Small scale cheese samples exceeded } \\
\text { the permissible limit }\end{array}$} & \multicolumn{2}{|c|}{$\begin{array}{l}\text { Large scale cheese samples exceeded } \\
\text { the permissible limit }\end{array}$} & \multicolumn{2}{|c|}{$\begin{array}{l}\text { Imported cheese samples exceeded } \\
\text { the permissible limit }\end{array}$} \\
\hline & & No. & $\%$ & No. & $\%$ & No. & $\%$ \\
\hline Lead & 0.3 & 6 & $20 \%$ & 4 & $13.33 \%$ & 3 & $10 \%$ \\
\hline Cadmium & 0.05 & 2 & $6.67 \%$ & 2 & $6.67 \%$ & 2 & $6.67 \%$ \\
\hline Mercury & 0.02 & 0 & $0 \%$ & 0 & $0 \%$ & 0 & $0 \%$ \\
\hline Cupper & 0.3 & 9 & $30 \%$ & 7 & $23.33 \%$ & 7 & $23.33 \%$ \\
\hline Zinc & 20 & 0 & $0 \%$ & 0 & $0 \%$ & 0 & $0 \%$ \\
\hline
\end{tabular}

$c-[65]$.

Table 5. Previous related results of analysed heavy metals from various parts of the world

\begin{tabular}{llllll}
\hline & Lead & Cadmium & Zinc & Cupper & Mercury \\
\hline Amer et al. [66] (Egypt) & $1.182 \pm 0.074$ & $0.212 \pm 0.011$ & $0.760 \pm 0.104$ & $0.014 \pm 0.000$ & $0.053 \pm 0.002$ \\
Aly et al.[67] (Saudi Arabia) & $0.47 \pm 0.07$ & $0.14 \pm 0.11$ & $7.19 \pm 0.47$ & $0.16 \pm 0.0001$ & - \\
Acar, [68] (Turkey) & $0.17 \pm 0.03$ & - & - & $0.67 \pm 0.19$ & $11.7 \pm 2.57$ \\
Bakircioglu et al.[20] (Turkey) & $4.15 \pm 0.18$ & $0.053 \pm 0.005$ & $23.7 \pm 2.8$ & $16.9 \pm 1.2$ & - \\
Thabet et al.[28] (Yemen) & $0.53 \pm 0.35$ & $0.73 \pm 0.18$ & - & $1.56 \pm 1.59$ & - \\
Rezaei et al.[51] (Iran) & $18.2 \pm 9.6$ & $5.4 \pm 2.7$ & - & - & $27.2 \pm 11.6$ \\
\hline
\end{tabular}

\section{Conclusion}

In conclusion, the results revealed the presence of OTA, AFM1 and heavy metals with different concentration in the examined cheese samples which is considered as a risk factor in dairy production. So it is highly recommended that controlling measures should be taken promptly to reduce contamination such as implementing a food control systems (such as HACCP) and educating dairy farmers and manufacturers. Additionally, it is suggested that subsequent studies should be conducted on these chemical contaminants in different stages of milk preparing and processing. There's a need for regular monitoring and a more stringent food safety management system (FSMS) in order to control these contaminants at the lowest possible levels.

\section{References}

[1] Enb, A., Abou Donia, M.A., Abd-Rabou, N.S., Abou-Arab, A.A.K. and El-Senaity, M.H. Chemical composition of raw Milk and heavy metals behavior during processing of milk products. Global Veterinaria. 3, 2009, P.268-275.
[2] Awad, E.I., Abdelfattah M. E., Abdelkaliek, A.A. and El-diasty, E.M. Prevalence of ochratoxin in small and large scale produced roomy cheese in Sharkia Governorate. World Rural Observations. 4, 2012.

[3] Lindqvist, R., Sylven, S. I. and Vagsholm, I. Quantitative microbial risk assessment exemplified by Staphylococcus aureus in unripened cheese made from raw milk. International Journal Food Microbiology. 78, 2002, P.155-170.

[4] Bennett, J. W. and Klich, M. Mycotoxins. Clinical Microbiology Reviews.16, 2003, P.497-516.

[5] Hedayati, M. T., Pasqualotto, A. C., Warn, P. A., Bowyer, P. and Denning, D. W. Aspergillus flavus: human pathogen, allergen and mycotoxin producer. Microbiology. 153, 2007, P. 1677-1692.

[6] Jouany, J. P. Mycotoxins in feed and their fate in animals. Animal Research. 51, 2002, P.81-99.

[7] Dashti, B., Al-Hamli, S., Alomirah, H., Al-Zenki, S., Bu Abbas, A. and Sawaya, W. Levels of aflatoxin M1 in milk, cheese consumed in Kuwait and occurrence of total aflatoxin in local and imported animal feed. Food Control Journal. 20, 2009, P. 686-690. 
[8] Sassahara, M., Pontes, N. D. and Yanak, E. K. Aflatoxin occurrence in foodstuff supplied to dairy cattle and aflatoxin M1 in raw milk in the North of Parana state. Food and Chemical Toxicology. 43, 2005, P.981-984.

[9] IARC, (International Agency for Research on Cancer): Some traditional herbal medicines: Some mycotoxins, naphthalene and styrene. IARC Monograph on the Evaluation of Carcinogenic Risks to Humans, World Health Organization, Lyon, France. 82, 2002, P.1-556.

[10] Tajkarimi, M., Aliabadi-Shojaee, F., Salah Nejad, A., Pursoltani, H., Motallebi, A. A.and Mahdavi, H. A flatoxin M1 contamination in winter and summer milk in 14 states in Iran. Food Control. 19, 2008, P. 1033-1036.

[11] Picinin, L.C.A., Cerqueira, M.M.O.P., Vargas, E.A., Lana, A.M.Q., Toaldo, I.M. and Bordignon-Luiz, M.T. Influence of climate conditions on a flatoxin M1 contamination in raw milk from Minas Gerais State, Brazil Food Control Journal. 31, 2013 , P.419-42.

[12] Zerfiridis, G. K. Potential a flatoxin hazards to human health from direct mold Teleme cheese. Journal of Dairy Science. 68, 1985, P.2184-2188.

[13] Deveci, O. and Sezgin, E. Change in concentration of aflatoxin M1 during manufacture and storage of skim milk powder. Journal of Food Protection. 69, 2006, P.682-685.

[14] Lopez, C., Ramos, L., Ramadan, S., Bulacio, L. and Perez, J. Distribution of aflatoxin M1 in cheese obtained from milk artificially contaminated. International Journal of Food Microbiology. 64, 2001, P.211-215.

[15] IARC. Monograph (International Agency for Research on Cancer). Monograph on the evaluation of carcinogenic risks to humans. International Agency for Research on Cancer. 56, 1993, P.11-116.

[16] Clark, H. A. and Snedecker, S. M. Ochratoxin A: Its cancer risk and potential for exposure. Journal of Toxicology and Environmental Health B. 9, 2006, P.265-296.

[17] Varga, J., Frisvad, J. C. and Samson, R. A. Two new a flatoxin producing species and an overview of aspergillus section flavi. Studies in Mycology. 69, 2011, P.57-80.

[18] Tornadijo, M. E., Fresno, J.M., Sarmiento, R.M. and Carballo, J Penicillium species during the manufacturing and ripening of Armada raw goat's milk cheese: Identification, characteristics in vitro potential toxins production. Lait. , Journal Paper Number 12,451 of the Furdue University comsposing author. Agricultural Experiment Station. 78, 1998, P.661-672.

[19] Ayar, A., Durmus-Sert, D. and Akın, N. The trace metal levels in milk and dairy products consumed in middle Anatolia, Turkey. Environ. Monit. Assess. 152, 2009, P.0167-6369 (print) and P.1573-2959 (online).

[20] Bakircioglu, D., Kurtulus, Y.B. and Ucar, G. Determination of some traces metal levels in cheese samples packaged in plastic and tin containers by ICP-OES after dry, wet and microwave digestion. Food and Chemical Toxicology. 49, 2011, P. 202-207.

[21] McCally, M. Human health and heavy metals exposure. The Environment and Human Health (Chapter 4). 2002.
[22] Akhter, P., Baloch, N.Z., Mohammad, D., Orfi, S.D. and Ahmad, N. Assessment of strontium and calcium levels in Pakistani diet. Journal of Environmental Radioactivity. 73, 2004, P.247-256.

[23] Siddiqui, I., Sirajuddin, N.S., Khan, F.A., Shahid, B., Tahir, M., Munshi, A.B. and Noman, S. Determination of some heavy metals in hen eggs using ICP - AES technique. Pakistan Journal of Biochemical Molecular Biology. 44, 2011, P.133 136.

[24] Noel, L., Chekri, R., Millour, S., Vastel, C., Kadar, A., Sirot, V., Leblanc, J.C. and Guerin, T. Li, Cr, Mn, Co, Ni, Cu, Zn, Se and Mo levels in foodstuffs from the Second French TDS. Food Chemistry.132, 2012, P.1502-1513.

[25] Hansen, T.J. Quantitative testing for mycotoxins. VICAM. American Association of cereal. Chemists. 1993, Inc. 38/5-8.

[26] Amer. A.A. and Ibrahim, M.A.E. Determination of aflatoxin M1 in raw milk and traditional cheeses retailed in Egyptian markets. Journal of Toxicology and Environmental Health Sciences. 2, 2010,p. 50-53.

[27] Gijs, Du. L., Filip, M.G. and Tack, M. G. V. Performance of selected destruction methods for the determination of heavy metals in reed plants. (Phragmites australis) Analytica Chimica Acta. 497, 2003, P.191-198.

[28] Thabet, H.M., Nogaim, Q.A., Alazaze, T.A., Alabadli, Y.S. and Aon, S.A. Microbiological Characteristics and Mineral Content of Local Smoked cheese produced in Yemen. Journal of Food and Nutrition Sciences. 1, 2013, P.65-71.

[29] Pattono, D., Grosso, A., Stocco, P.P., Pazzi, M. and Zeppa, G. Survey of the presence of patulin and ochratoxin A in traditional semi- hard cheeses .Food Control Journal. 33, 2013 ,P. 54-57.

[30] Montagna, M.T., Santacroce, M. P., Spilotros, G., Napoli, C., Minervini, F. and Papa, A. Investigation of fungal contamination in sheep and goat cheeses in southern Italy. Mycopathologia. 158, 2004, P.245-249.

[31] Søresen, L. M., Jacobsen, T., Nielsen, P. V., Frisvad, J. C. and Koch, A. G. Microbiota in the processing areas of two different meat products. International Journal of Food Microbiology. 124, 2008, P.58-64.

[32] López-Diaz, T. M.-Santos, J. A.- García-López, M. L. and Otero, A.: Surface mycoflora of a Spanish fermented meat sausage and toxigenicity of Penicillium isolates. International Journal of Food Microbiology.68, 2001, P.69-74.

[33] Sorhaug, T. Spoilage Molds in Dairy Products.Encyclopedia of Dairy Sciences (Second Edition). 2011, P. 780-784.

[34] Pestka, J.J. and Bondy, G.S. Toxicology of mycotoxins In: Mycotoxins in Grain, Compounds other than Aflatoxin, Miller, J.D. and Trenholm, H.L. (ed.). 1994, p. 339-358. Eagan Press. St. Paul, MN.

[35] Prelusky, D.B., Rotter, B.A. and Rotter, R.G. Toxicology of mycotoxins. In: Mycotoxins in Grain, Compounds Other than Aflatoxin, Miller, J.D. and Trenholm, H.L. (ed.). 1994, p. 359-403. Eagan Press. St. Paul, MN.

[36] Beardall, J.M. and Miller, J.D. Diseases in humans with mycotoxins as possible causes. 1994. Residues in food products of animal origin. In: Mycotoxins in Grain, Compounds other than Aflatoxin, Miller, J.D. and Trenholm, H.L. (ed.). p. 487-539. Eagan Press. St. Paul, MN. 
[37] Kamkar, A. A study on the occurrence of a flatoxin M1 in Iranian Feta cheese. Food Control. 17, 2006, P. 768-775.

[38] Tekinsen, K. K. and Ucar, G. Aflatoxin M1 levels in butter and cream cheese consumed in Turkey. Food Control. 19, 2008, P.346-349.

[39] Tavakoli, H.R., Riazipour, M., Kamkarc, A., Shaldehi, H.R. and Nejad, A.S.M. Occurrence of a flatoxin M1 in white cheese samples from Tehran, Iran. 2012.

[40] Elkak, A., El Atat, O., Habib, J. and Abbas, M. Occurrence of a flatoxin M1 in cheese processed and marketed in Lebanon Control. Food Control. 25, 2012, P. 140-143.

[41] Mohajeri, F.A., Ghalebi, S.R., Rezaeian, M., Gheisari, H.R., Azad, H.K., Zolfaghari, A. and Fallah, A.A. Aflatoxin M1 contamination in white and Lighvan cheese marketed in Rafsanjan, Iran .Food Control Journal. 33, 2013, P.525-527.

[42] Deveci, O. Changes in the concentration of a flatoxin M1 during manufacture and storage of white pickled cheese. Food Control Journal. 18, 2007, P.1103-1107.

[43] Oruc, H. H., Cibik, R., Yilmaz, E.and Kalkanli, O. Distribution and stability of a flatoxin M1 during processing and ripening of traditional white pickled cheese. Food Additives and Contaminants. 23, 2006 , P.190-195.

[44] Yapar, K., Elmali, M., Kart, A. and Yaman, H. Aflatoxcin M1 levels in different type of cheese products produced in Turkey. Medycyna Weterynaryjna. 64, 2008, P.53-55.

[45] El-Tras, W.F., El-Kady, N.N. and Tayel, A.A. Novel food-borne zoonosis. Food and Chemical Toxicology. 49, 2011, P. 2816-2819.

[46] Akkaya, L., Birdane, Y. O., Oguz, H. and Cemek, M. Occurrence of aflatoxin M1 in yogurt samples from Afyonkarahisar, Turkey. Bulletin of the Veterinary Institute in Pulawy. 50, 2006, P.517-519.

[47] Buldu, H. M., Koc, A. N. and Uraz, G. Aflatoxin M1 contamination in Cow's milk in Kayseri (Central of Turkey).Turkish Journal of Veterinary and Animal Sciences. 35, 2011, P.1-5.

[48] Wogan, G.N., Hecht, S.S., Felton, J.S., Conney, A.H. and Loeb, L.A. Environmental and chemical carcinogenesis. Seminars in Cancer Biology. 14, 2004, P. 473-486.

[49] Caloni, F., Stammati, A., Friggè, G. and De Angelis, I. Aflatoxin M1 absorption and cyto-toxicity on human intestinal in vitro model. Toxicon. 47, 2006, P.409-415.

[50] Coni, E., Bocca, A., Lanni, D. and Caroli, S. Preliminary evaluation of the factors influencing the trace element content of milk and dairy products. Food Chemistry. 52, 1995, P. 123-130.

[51] Rezaei, M., Dastjerdi, H.A., Jafari, H., Farahi, A., Shahabi, A., Javdani, H., Teimoory, H., Yahyaei, M. and Malekirad, A.A. Assessment of dairy products consumed on the Arakmarket as determined by heavy metal residues .Health.6,2014,P.323-327 .

[52] Muncke, J. Exposure to endocrine disrupting compounds via the food chain: is packaging a relevant source? Sci. Total Environ. 407, 2009, P.4549-4559.
[53] US Environmental Protection Agency. Integrated Risk Information System, "Lead and compounds (inorganic)",2003 (CASRN7439-92-1).Downloaded from: http://www.epa.gov/ iris/subst/0277. htm on 20/11/2012.

[54] FAO/WHO. Code of Practice for the Prevention and Reduction of Lead Contamination in Foods CAC/RCP (56-2004). FAO/WHO: Rome, Italy, 2004, pp. 1-5. Available from: http://www.codex alimentarius.net/dow-nload/ standards/ 10099/CXC_056_2004e.pdf/.

[55] Johnson, M.D., Kenney, N., Stoica, A., Hilakivi-Clarke, L., Singh, B., Chepko, G., Clarke, R., Sholler, P.F., Lirio, A.A. and Foss, C. Cadmium mimics the in vivo effects of estrogen in the uterus and mammary gland. Nature Medicine. 9, 2003, P. 1081-1084.

[56] Järup, L. Hazards of heavy metal contamination. Br. Med. Bull. 68, 2003:167-82.

[57] Navas-Acien, A., Tellez-Plaza, M., Guallar, E., Muntner, P., Silbergeld, E., Jaar, B. and Weaver, V. Blood cadmium and lead and chronic kidney disease in U.S. adults: a joint analysis. American Journal of Epidemiology. 170, 2009, P.1156-1164.

[58] Manahan, S. Toxiological Chemistry. A guide to toxic substances in chemistry. Brooks/cole publishing Co. C. A., 1989.

[59] Sarkar, B., Laussac, J. and Lau, S. Transports forms of copper in human serum. In: Sarkar, B. (ed): biological aspects of metals and metal related diseases. New York: Raven press. 1983, pp. 23-40.

[60] Lee, R. Zinc. In: harbison R. (ed): Hamilton and Hardy's industrial toxicology. $5^{\text {th }}$ edition, 1998, p.139-144.

[61] Berman, E. Toxic metals and their analysis. Heyden and San Ltd., London, 1980.

[62] Walshe, C., Sandstead, H. and Prasad, A. Health effects and research priorities for the 1990s. Environemental Health perspect. 102, 1994,P.5-16.

[63] Egyptian Standard 1875-2/Maximum Limits for Mycotoxins in Foods - Ochratoxins, 2010.

[64] Egyptian Standard 1- 1875. "Maximum levels of mycotoxin for foods and feeds, part-1: Aflatoxins" Egyptian Organization for Standardization and Quality, 2007.

[65] Egyptian standard. NO.2360. Maximum levels of heavy metal contaminants in food. Egyptian organization for standardiazation "E.O.S.",1993

[66] Amer, I.H., El Sayed, M.S. and Abd-El Aal, S.F.A. The preliminary content of heavy metal residues in raw cows milk and its distribution in some dairy products. Zagzig Veterinary Journal. Vol. 33, 2005, P.263-271.

[67] Aly, M.M., Al-Seeni, M.N., Qusti, S.Y. and El-Sawi, N.M. Mineral content and microbiological examination of some white cheese in Jeddah, Saudi Arabia during summer 2008. Food and Chemical Toxicology. 48,2010,p. 3031-3034

[68] Acar, O. Determination and Evaluation of Copper, Lead, Iron and Zinc Contamination Levels in Cheese and Tahini Halva by Atomic Absorption Spectrometry. Journal of Food Safety. 13, 2011, p.45-53. 